\title{
KETERTIBAN YANG ADIL VERSUS KETIDAKADILAN: BEBAN SOSIAL-EKONOMI YANG HISTORIS DARI HUKUM
}

\author{
Budiono Kusumohamidjojo \\ email: budikoesoemo@gmail.com
}

\begin{abstract}
This paper is based on a two decade observation on the dilemma of order and justice, leading to an attempt to analyze the social-economic factors underlying the historical roots of injustice. On its course it attempted to take lessons from historically proven axioms provided by certain heavy weight thinkers. While trying to make the best out of those axioms, the analysis could not ignore the hard facts of the daily life of the billions of people suffering from unending injustice in most parts of the world, in the rich and let alone in the poor parts of it. Neither could it escape from criticizing the ubiquitous mess in the justice system, almost universally. Although the overall problem of injustice does not seem to provide much hope for a better life of the people at large, the conclusion of this paper tried to distant away from a pessimistic stance and instead proposed an agenda for those who may concern to be carried out. This paper contains forethoughts of a book in the making regarding basically the same problem.
\end{abstract}

Keywords:

history, authority, rationality, law, order, equality, justice.

\begin{abstract}
Abstrak
Tulisan ini dibuat berdasarkan pengamatan yang dilakukan selama dua dekade perihal dilema ketertiban dan keadilan. Dilema yang mendorong ikhtiar menganalisis faktor-faktor sosialekonomi yang menjadi latar belakang akar historis dari ketidakadilan. Penelaahan yang dilakukan mencoba menarik pelajaran dari aksioma-aksioma yang terbukti validitasnya dalam lintasan sejarah sebagaimana diajukan para pemikir tingkat dunia. Sembari melandaskan diri pada aksioma-aksioma tersebut, tulisan ini tidak dapat begitu saja mengenyampingkan fakta telanjang miliaran manusia yang menderita karena berlanjutnya ketidakadilan di berbagai belahan dunia, baik di bagian negara-negara kaya maupun negara-negara miskin. Telaahan yang dilakukan juga tidak mungkin mengabaikan perlunya mengkritisi kekacauan terang benderang dari sistem peradilan di hampir semua negara. Sekalipun persoalan besar ketidakadilan tidak memberikan banyak harapan bagi terciptanya kehidupan lebih baik bagi banyak orang, kesimpulan dalam tulisan ini mencoba membuat jarak dari pandangan pesimis dan sebaliknya mengajukan usulan bagi sejumlah perbaikan. Tulisan ini memuat pemikiran-pemikiran awal yang akan dituangkan lebih lanjut oleh penulis dalam buku yang masih akan ditulisnya perihal persoalan mendasar serupa.
\end{abstract}

Kata Kunci:

sejarah, kekuasaan, rasionalitas, hukum, ketertiban, kesetaraan, keadilan.

\section{Pengantar}

\section{Ketertiban yang Adil}

Gagasan untuk membahas "ketertiban yang adil" berangkat dari observasi terhadap fakta sosial historis manusia, bahwa pertama: ketidaktertiban tidak 
mungkin menghasilkan keadilan, tetapi juga sebaliknya, bahwa kedua: ketidakadilan juga akan menghasilkan ketidaktertiban, padahal ketiga: tidak ada masyarakat manusia yang dapat berlangsung secara kondusif bagi kepentingan manusia sendiri jika kehidupan bersama mereka terus-menerus berada dalam keadaan tidak tertib. Jadi sulit untuk meragukan, bahwa ketertiban merupakan kunci awal bagi masyarakat manusia yang manapun dan pada segala tingkatan: dari tingkat rukun tetangga sampai ke tingkat global supaya kehidupan bersama dapat berlangsung sesuai dengan kodrat manusia sendiri yang pada umumnya mendambakan kebahagiaan (Sokrates, 469-399 SM: eudaimonia) dan pada akhirnya meliputi ketertiban, perdamaian, kesejahteraan serta keadilan.

Gagasan "ketertiban yang adil" yang saya ajukan menanggung risiko untuk dicap sebagai gagasan yang berbau imperialistik (Lat, imperare: menguasai), karena bisa mengingatkan orang kepada tanda kehormatan "Orde en Vrede" (Ketertiban dan Perdamaian) yang diadakan oleh Ratu Belanda Wilhelmina (1880-1962) pada tanggal 12 Desember 1947.1 Tanda kehormatan itu dianugerahkan kepada tentara Belanda yang terlibat dalam "politionele acties" di kurun waktu 21 Juli - 5 Agustus 1947 (Aksi Polisionil I) dan 19 Desember 1948 5 Januari 1949 (Aksi Polisionil II) untuk mempertahankan kekuasaan Belanda atas Indonesia.

Meskipun demikian, gagasan "ketertiban yang adil" yang saya ajukan semata-mata bertolak dari logika yang realistik, yaitu pertama, bahwa tanpa ketertiban kita tidak bisa mencapai apapun, dan kedua, bahwa ketertiban hanya bisa dipertahankan secara langgeng jika dia memajukan keadilan. Penarikan kesimpulan, bahwa ketertiban juga bisa menjadi alat kekuasaan yang absolut dan despotik, tidak penulis sangkal, tetapi kekuasaan yang absolut dan despotik yang masih bercokol di banyak negara itu justru menghasilkan ketertiban yang tidak adil.

${ }^{1}$ Ereteken voor Orde en Vrede, dalam: Wikipedia, https://nl.wikipedia.org/wiki/Ereteken_voor Orde_en_Vrede, 23-06-2015. 
Ketertiban yang kita perlukan harus merupakan produk dari hukum yang rasional, untuk bisa menjadi tempat berpijak bagi mereka yang ingin "ngobrol" mengenai apa itu keadilan. Logika yang mengedepankan ketertiban sebagai conditio sine qua non untuk bisa membangun keadilan itu bertolak dari fakta bahwa gagasan keadilan itu adalah perkara yang sebenarnya tidak pernah jelas betul yang karena itu justru membuatnya rentan untuk bermuara sebagai ketidakadilan. Karena itu perjuangan yang mengibarkan semboyan "menegakkan kebenaran dan keadilan" sebenarnya lebih merupakan hasutan untuk massa rakyat banyak yang menderita terlalu lama dan terlalu mendalam, karena seharusnya kita selalu bertanya: kebenaran yang mana dan keadilan yang mana? Orang terlalu sering gampang meneriakkan "demi kebenaran dan keadilan", sehingga kehidupan bersama manusia selalu terjebak dalam kontradiksi keadilan versus ketidakadilan, dan lebih miris lagi: kebenaran versus ketidak-benaran.

Suatu keadaan tertib bisa bersifat damai, meskipun tidak adil, seperti Irak di zaman Saddam Hussein (1937-2006). Satu kali saya membaca kisah dari seorang diplomat negara Barat yang pernah ditempatkan di Baghdad dan menceritakan betapa di zaman Saddam Hussein berkuasa dia pernah lupa mengunci mobil BMW-nya yang diparkir di tepi jalan, dan mendapatkannya keesokan harinya tanpa kekurangan sesuatu apa. Betapa bedanya dengan keadaan setelah Amerika Serikat "membawa demokrasi” ke Irak yang membuatnya tidak tertib, tidak damai, tidak adil dan tidak sejahtera! Sebaliknya, suatu keadaan tertib bisa juga tidak menghasilkan apapun yang diperlukan bagi suatu kehidupan bersama manusia yang manusiawi. Keadaan ini bisa kita amati di negara-negara atau wilayah-wilayah yang saya hindari untuk menyebutkannya.

\section{Ketertiban Umum}

Dalam Il Principe Niccolo Machiavelli (Firenza, 1469-1527) ada mengemukakan contoh yang bengis dari apa yang dilakukan oleh Cesare Borgia (Valencia, Spanyol, 1475-1507) untuk menegakkan ketertiban di antara penduduk Romagna (Italia barat laut) yang ditundukkannya. Penduduk Romagna itu 
berontak terhadap penindasan yang mereka alami selama dan setelah kampanye penaklukan mereka oleh Cesare Borgia. Penakluk ini lantas berjanji kepada penduduk Romagna untuk menghukum "mereka yang bersalah". Dia kemudian menuding sejumlah panglima perangnya, dan mengeksekusi mereka sebagai “orang-orang yang paling bertanggungjawab" untuk penderitaan rakyat itu (tahun 1502). Dengan cara begitu Cesare Borgia menegakkan ketertiban, sambil membayarnya dengan ketidakadilan yang brutal terhadap para panglimanya, namun memuaskan rasa adil yang semu dan ironis di kalangan rakyat yang protes kepadanya. $^{2}$

Jangan kita terbuai oleh ilusi, seolah-olah dalam abad ke-21 tidak ada lagi praktik brutal dan bengis seperti itu, dalam skala besar maupun apalagi yang kecil dan tidak terekspos di media dunia. Saya tidak menyangkal adanya negara-negara yang makmur dan rakyatnya tidak banyak mengeluh mengenai ketertiban maupun keadilan dalam keseharian hidup mereka. Namun untuk bagian terbesar umat manusia abad ke-21, ketertiban yang adil itu masih jauh panggang dari api, lebih-lebih karena pemahaman mengenai konsep ketertiban yang aneka ragam.

Upaya untuk membangun ketertiban yang adil tidak bisa menghindar untuk harus berangkat dari pengertian ketertiban umum (Eng: public order; Ned: openbare orde; Deu: öffentliche Ordnung), yaitu suatu keadaan sosial yang relatif teratur yang merupakan kepentingan dari umumnya warga masyarakat. Dalam setiap masyarakat selalu ada elemen-elemen yang dapat menikmati tingkat ketertiban umum yang rendah. Karena itu pada tingkat yang paling mendasar, ketertiban umum itu ditegakkan dengan pengendalian terhadap perbuatanperbuatan kriminal umumnya seperti yang difahami di Amerika Serikat:

"Ketertiban umum merupakan suatu kondisi yang ditandai oleh tidak adanya kekerasan kriminal dan kekerasan politik yang luas seperti penculikan, pembunuhan, kerusuhan, pembakaran, dan intimidasi terhadap kelompok-kelompok maupun individu-individu sasaran tertentu. ... Dalam kondisi ini kekerasan-kekerasan itu direduksi

\footnotetext{
2 Machiavelli, Niccolo, Der Fürst, (dari versi Italia, Il Principe, oleh Rudolf Zorn), Stuttgart: Alfred Kröner, 1977: Bab VII.
} 
sampai kepada tingkat minimum yang dapat "ditoleransi", di mana para pelakunya dikejar, ditangkap, ditahan, dan di mana penduduk dapat bergerak bebas tanpa takut pada kekerasan-kekerasan serupa itu..."

Ketertiban umum seperti ini lebih ditandai oleh rendahnya tingkat kekerasan dalam masyarakat, seperti yang menjadi fokus berikut ini:

"Ketertiban umum merupakan ranah polisi maupun badan-badan pengamanan lain: pengadilan, kejaksaan, dan penjara, yang semuanya merupakan bagian struktural dari suatu sistem hukum pidana...."3

Padahal makna ketertiban umum tidaklah seterbatas itu karena juga melibatkan aspek-aspek lain dari kehidupan bersama yang terjangkar dalam tertib sosial (Eng: social order; Ned: maatschappelijke orde; Deu: soziale Ordnung), yaitu tatanan sistemik yang terjalin dari struktur yang utuh dan bersandar pada pranata-pranata sosial (Eng: institutions, bukan institutes, lembaga), serta interaksi dan kebiasaan terpola antar sesama anggota dari suatu komunitas yang dikembangkan oleh manusia, untuk mengatur harmoni antara status dan peranan masing-masing warga, dalam suatu keteraturan yang terus-menerus dibina dan ditaati secara langgeng, demi tegaknya komunitas yang bersangkutan. ${ }^{4}$

Karena suatu tertib sosial selalu merupakan ekspresi kebudayaan yang nota bene adalah aneka ragam, menjadi logis semata jika konsep ketertiban umum yang bertumpu padanya juga difahami secara berbeda dari satu masyarakat ke masyarakat yang lain. Kenyataan itu nampaknya melatar-belakangi masalah yang ada pada sistem hukum kita maupun di negara-negara lain:

'Embel-embel 'ketertiban umum' hampir ditemukan pada setiap perangkat perundang-undangan di Indonesia. Namun, definisi 'ketertiban umum' hingga kini belum jelas alias masih simpang siur."

\footnotetext{
3 United States Institute of Peace, Public Order, dalam: http://www.usip.org/guiding-principlesstabilization-and-reconstruction-the-web-version/7-rule-law/public-order, 14-01-2015.

4 Meminjam konsep dari Kornblum, William, Sociology in a Changing World, Belmont CA/Thomson Wadsworth, 2005, hlm., 81-86.

5 Dikutip dari: Definisi 'Ketertiban Umum' Masih Simpang Siur, dalam: http://www.hukumonline. com/berita/baca/hol998/definisi-ketertiban-umum-masih-simpang-siur, 14-01-2015.
} 
Padahal, "definisi" mengenai "ketertiban umum" itu penting, karena:

"Ketidaktertiban umum dapat secara mendasar mengganggu stabilitas dari masyarakat-masyarakat ... dan dapat menyebar rasa ketakutan yang konstan di kalangan penduduk, menghambat upaya-upaya untuk memperkuat lembaga-lembaga keamanan negara dan mengganggu keberhasilan dari proses-proses pendamaian. Kegiatan-kegiatan yang dimotivasi secara kriminal maupun politik kerap kali disertai dengan pelanggaran luas terhadap hak asasi manusia seperti penyiksaan, perkosaan, perlakuan yang kejam, tidak manusiawi atau merendahkan, serta penangkapan dan penahanan yang semena-mena. Penduduk tidak mempunyai banyak pilihan untuk menangani ancaman-ancaman itu. Polisi biasanya kekurangan tenaga, dan juga sarat dengan penyalahgunaan kekuasaan serta korupsi. Hakim juga kurang dan mereka dilanda oleh ketidak-percayaan dari masyarakat terhadap kemampuan mereka untuk mengadili perkara-perkara secara independen. Penjara-penjara juga penuh. Tanpa ketertiban umum orang tidak akan membangun kepercayaan terhadap sistem keamanan publik dan akan mencari keamanan dari kekuatankekuatan lain seperti dari para milisi dan pendekar-pendekar liar." ${ }^{6}$

Berbeda dari pemahaman di Amerika di mana konsep ketertiban umum memperoleh pemahaman lebih sebagai "ketertiban kepolisian", di Jerman pengertian itu lebih relevan sebagai "ketertiban hukum":

"Pengadilan Tinggi Administrasi Prusia pada tahun 1933 memahami ketertiban hukum sebagai keseluruhan aturan-aturan yang tidak tertulis mengenai perilaku individu dalam masyarakat, sejauh berdasarkan pandangan umum ketaatan terhadap aturan-aturan itu dipandang merupakan syarat yang tidak dapat dihindari demi suatu kehidupan masyarakat yang tertib."

Sedangkan Mahkamah Konstitusi Jerman memahami ketertiban umum sebagai:

“... keseluruhan aturan-aturan yang tidak tertulis, yang ketaatan terhadapnya berdasarkan pandangan sosial dan etis pada umumnya dipandang sebagai syarat yang tidak dapat dihindari, demi suatu kehidupan masyarakat yang tertib di suatu kawasan tertentu."7

${ }^{6}$ Dikutip dari: United States Institute of Peace, Public Order, dalam: http://www.usip. org/guiding-principles-stabilization-and-reconstruction-the-web-version/7-rule-law/publicorder, 14-01-2015.

7 Dikutip dari: Öffentliche Ordnung, dalam: http://de.wikipedia.org/wiki/\%C3\%96ffentliche_ Ordnung, 14-01-2015. 
Jika rumus atau pengertian "ketertiban umum" ternyata tidaklah cukup tegas, dan pengertian "keadilan" adalah lebih tidak jelas lagi, maka dilema ketertiban dan keadilan menjadi persoalan klise: kehidupan bersama manusia yang manusiawi hanya mungkin jika dia adalah "tertib dan adil" sekaligus.

Padahal, evolusi kehidupan bersama manusia memperlihatkan, bahwa pokok persoalan bagi manusia sebagai kehidupan bersama adalah realisasi hukum, karena hukum itulah yang mengatur perilaku antar warga masyarakat, supaya kehidupan bersama mereka itu bisa berlangsung lumayan tertib dan adil. Tanpa hukum kehidupan bersama itu akan menjadi medan konflik antar warga masyarakat seperti yang dirumuskan oleh Thomas Hobbes (1588-1679) dalam abad ke-17 sebagai homo homini lupus (setiap orang adalah serigala bagi sesamanya). Dalam Leviathan dia memberikan gambarannya yang terkenal, bahwa tanpa hukum, hidup manusia menjadi "solitary, poor, nasty, brutish and short" (sunyi, papa, jorok, brangas dan pendek). ${ }^{8}$

Masalahnya adalah, betapa pun suatu pemerintah yang terbaik yang bisa ada di dunia ini hendak menegakkan ketertiban yang adil, suatu tatanan ketertiban itu sering menghadapi tantangan, bahwa:

a) ketertiban itu kerap kali didasarkan pada suatu keadaan yang ditentukan oleh suatu pemegang kedaulatan yang membuatnya kapan saja bisa mengesampingkan bagian-bagian tertentu dari hukum positif, misalnya apa yang sering disebut sebagai "keadaan darurat militer" (Ned: staat van oorlog en beleg) seperti yang pernah lama dialami di Indonesia berdasarkan Keputusan Presiden Republik Indonesia Serikat No. 22 tahun 1950 dan berlaku sampai tahun 1959. Dengan cara itu semua atau sebagian warga masyarakat dikucilkan dari arus besar hukum yang berlaku; ${ }^{9}$ atau

b) ketertiban itu memang didasarkan pada suatu tata hukum tertentu tetapi ternyata tidak menghasilkan banyak keadilan, seperti yang dapat disaksikan di

8 Hobbes, Thomas, Leviathan (versi Jerman dari Jacob Peter Mayer), Stuttgart: Philipp Reclam, 1980: Bab XIII.

9 Masalah ini dibahas terutama oleh Agamben, Giorgio, Homo Sacer: Sovereign Power and Bare Life (1995); State of Exception. Homo Sacer II, 1 (2003); State of Exception (2005). 
banyak negara yang masih jatuh bangun dalam usahanya untuk menegakkan negara hukum. Orang banyak memang menikmati suatu ketertiban umum tertentu, tetapi menjalaninya secara untung-untungan, karena kapan saja dia bisa menjadi korban dari kesemena-menaan kekuasaan, pelanggaran hukum atau tidak jarang juga dari suatu ketidakadilan yang struktural; atau

c) ketertiban itu menghasilkan suatu situasi minus malum (Lat: yang paling baik di antara yang buruk) karena menghasilkan suatu keadilan yang relatif diterima umum, tetapi kadang-kadang terpaksa mendatangkan ketidakadilan, semata-mata karena ketertiban itu memang menghadapi keterbatasan summum ius, summa iniuria seperti kata Cicero.

Dari ketiga macam ketertiban tersebut, di negara kita sekarang banyak berlaku kombinasi dari dua jenis ketertiban yang terakhir yang dengan sendirinya tidak mungkin menjanjikan banyak untuk membuat kehidupan bersama menjadi lebih adil, paling sedikit supaya orang banyak tidak terlalu sering merasakan atau menjadi korban dari ketidakadilan.

\section{Keadilan versus Ketidakadilan}

Inspirasi tertua dalam sejarah untuk merumuskan "keadilan" nampaknya berasal dari Konfusius (Kongzi, 551-479 SM) yang mengemukakan gagasan mengenai "yi" yang berarti keadilan, kebenaran, tetapi lebih luas berarti "apa yang sebaiknya dilakukan pada suatu situasi tertentu." Konfusius mengajukan dua pemahaman dasar mengenai keadilan. Pertama: "Apa yang orang tidak mau terjadi pada dirinya, jangan orang itu melakukannya pada orang lain; apa yang orang inginkan bagi dirinya, itu juga yang dia harus berikan kepada orang lain.“10 Doktrin pertama ini 23 abad kemudian diajukan kembali oleh Immanuel Kant (Prusia, 1724-1804) dalam bentuk maxim yang tersohor sebagai "kategori imperatif." ${ }^{11}$ Sedangkan yang kedua menyatakan: "Balaslah yang jahat dengan

\footnotetext{
${ }^{10}$ Konfusius, Lùn-yŭ (dari versi Kuoyü oleh Richard Wilhelm, Gespräche. Lun Yü), München: dtv CH Beck, [2005] 2007: XV. 23.

${ }^{11}$ Immanuel Kant dalam Grundlegung zur Metaphysik der Sitten, Stuttgart: Philipp Reclam, [1786] 1976.
} 
keadilan, dan balaslah kebaikan dengan kebaikan."12 Doktrin Konfusius ini mungkin merupakan upaya yang tertua yang hendak menjelaskan, apa itu keadilan.

Orang memang tidak bisa mengharapkan "definisi" dalam konteks filsafat Tiongkok kuno seperti yang menjadi obsesi filsafat Barat sejak zaman Yunani kuno. Filsafat Barat yang bertumpu pada filsafat Yunani selalu terobsesi untuk mencari dan merumuskan apa itu kebenaran yang terdalam dan terakhir, yang menurut Konfusius: "bukanlah urusan kita."13

Dalam filsafat Tiongkok kuno suatu konsep pada umumnya tidak akan dirumuskan, melainkan direlasikan dengan kebalikannya, misalnya: berkata benar adalah adil, sedangkan berbohong adalah tidak adil. Doktrin Konfusius di Timur kemudian diimbangi di Barat oleh ajaran Platon (Athena, 428/427 atau 424/423348/347 SM), yang merumuskan konsep keadilan dalam Politea sebagai: "Setiap orang memiliki dan melakukan apa yang dimilikinya dan apa yang patut dilakukannya."14 Dengan demikian, sudah sejak Platon soal keadilan itu lekat dengan konsep "milik" dan "perbuatan".

Tujuh abad kemudian ahli hukum Romawi, Domitius Ulpianus (170-223) mengajukan pemahaman yang lebih tajam: "Keadilan adalah kehendak yang teguh dan sinambung untuk memberikan kepada siapapun apa yang menjadi haknya. Keharusan hukum itu adalah sebagai berikut: hidup terhormat, tidak melukai orang lain, dan memberikan kepada siapapun apa yang menjadi haknya."15 Pernyataan inilah yang kemudian menjadi terkenal melalui rumus singkatnya: "suum quique tribuere" atau: berikanlah kepada siapapun apa yang menjadi

${ }^{12}$ Lùn-yŭ: XIV.36.3.

${ }^{13}$ Lihat misalnya: Capra, Fritjof, The Tao of Physics: An Exploration of the Parallels between Modern Physics and Eastern Mysticism, Toronto/New York/London: Bantam, [1975] 1980.

14 Platon dalam Politeia, dikutip dari Bernd Rüthers, Das Ungerechte an der Gerechtigkeit, Tübingen: Mohr Siebeck, 2009, hlm., 160.

15 Domitius Ulpianus dalam Digest iustiniani 1,1,1,pr.: “ iustitia est constans et perpetua voluntas ius suum quique tribuendi. Ius praecepta sunt haec: honeste vivere, alterum non laedere, suum quique tribuere", dikutip dari: Heinrich Honsell, Römisches Recht, Berlin/Heidelberg/New York: Springer, 2002, hlm., 19. 
haknya. Dengan begitu Ulpianus maju satu langkah dari Platon dengan menjadikan konsep "hak" sebagai batu pijak bagi keadilan.

Kemudian terbukti, bahwa definisi Ulpianus tidaklah mengunci perdebatan mengenai masalah keadilan sehingga menjadi topik perenial dalam wacana mengenai negara. Tak kurang dari Aurelius Augustinus (Tunesia, 354-430) yang dua abad kemudian menyatakan bahwa "In the absence of justice, what is sovereignty but organized robbery?" Tetapi Augustinus juga mencatat apa yang dikatakan oleh seorang bajak laut kepada Sang Penakluk Alexander Akbar dari Macedonia (356-323 SM), murid dari Aristoteles (Athena, 384-322 SM), kurang lebih begini:

"Apa yang kau pikirkan, sehingga kau membuat dunia ini menjadi tidak aman? Tentu saja, karena aku berkeliaran dengan kapal kecil, aku disebut perampok. Sedangkan kamu melakukannya dengan armada besar dan disebut Sang Penguasa."16

Augustinus memperlihatkan bahwa perbedaan kedua despotisme itu bisa bersifat hanya gradual saja. Begitu juga halnya dengan ketidakadilan: ada yang sistematis, terstruktur dan masif yang menyengsarakan orang banyak, ada juga yang medioker dan terjadi sehari-hari tetapi terus menerus.

Di Indonesia abad ke-20 Satjipto Rahardjo (1930-2010) masih mengingatkan kita pada delapan rumus lagi mengenai keadilan dalam bukunya, masing-masing dari perspektif yang berbeda, antara lain dari Kaisar Yustinianus I (Byzantium, 483-565), Roscoe Pound (Amerika, 1870-1964), Hans Kelsen (Austria, 1881-1973) dan John Rawls (John Bordley Rawls, Amerika, 19212002). ${ }^{17}$ Namun yang menarik untuk saya adalah justru rumus yang dikutipnya dari Serat Sasangka Jati, yaitu bahwa:

" ... adil adalah tegak, tidak berat sebelah, oleh karena itu juga bisa diberi arti lurus atau benar, sedang benar itu juga berarti nyata, dan nyata itu adalah jujur..."18

\footnotetext{
16 Aurelius Augustinus dalam De civitate Dei (Lat: Negara Illahi), IV, 1, dikutip dari Bernd Rüthers, id., hlm., 165.

17 Satjipto Rahardjo, Ilmu Hukum, Bandung: PT Citra Aditya Bakti, 2000, hlm., 163-165.

18 Id., hlm., 166.
} 
Teranglah bahwa rumus ini lebih kompleks dari apa yang biasanya kita fahami dari "keadilan" itu dan bukanlah semata-mata sebagai proses give and take yang timbal-balik dan seimbang. Dalam konteks Serat Sasangka Jati bukan hanya soal ukur-mengukur berat sebelah atau tidak berat sebelah yang menghasilkan keadilan, melainkan pada akhirnya adalah sikap jujur yang nota bene bersemayam dalam hati nurani manusia dan tidak bisa dilihat atau dibaca oleh siapa pun. ${ }^{19}$ Padahal, kita tahu bahwa suara hati nurani tidaklah berperan dalam pelaksanaan hukum positif, seperti kata doktrin hukum Romawi di abad ke-3 TM: "De internis non iudicat praetor" (hakim tidak mengadili hati nurani), ${ }^{20}$ karena niat yang belum menjadi aktus sebagai perbuatan belumlah menyentuh kepentingan dari subjek hukum lain.

Kendati segala maksud baiknya, Ulpianus dan Serat Sasangka Jati bukannya tidak mewariskan tanda-tanya. Kehendak baik saja di dunia ini memang tidak cukup, atau lebih sering lagi: sangat tidak cukup. Hans Kelsen dan Bernd Rüthers (Jerman, 1930-) misalnya melancarkan kritik terhadap doktrin Ulpianus dengan argumen, bahwa rumus mengenai "hak" yang menjadi pijakannya itulah yang justru paling kontroversial. Keduanya sama-sama menyatakan bahwa rumus "berikanlah kepada siapapun apa yang menjadi haknya" adalah rumus yang hampa, terutama karena kita tidak pernah bisa tahu apa yang menjadi hak sebenarnya dari siapa. ${ }^{21}$

Kelsen adalah mantan hakim agung di Austria dan Rüthers adalah mantan hakim agung di Jerman, sehingga kritik itu tidak bisa dipandang ringan. Masalahnya adalah, keduanya meninggalkan kebuntuan yang diwariskannya kepada umat manusia, karena Hans Kelsen berujar untuk menutup booklet-nya: "saya tidak tahu dan tidak dapat mengatakan, apa itu keadilan, keadilan absolut, impian indah kemanusiaan", dan juga Bernd Rüthers: "Apa itu keadilan? Saya

19 Paragraf ini saya sadur dari Kusumohamidjojo, Filsafat Politik: Kotak Pandora Abad ke-21, Jalasutra, Yogyakarta, 2015.

20 Theo Huijbers, Filsafat Hukum, Kanisius, Yogyakarta, 1991, hlm., 75.

${ }^{21}$ Kelsen, Hans, Was ist Gerechtigkeit?, Stuttgart: Philipp Reclam, 2010: 32; juga Rüthers, Id., hlm., 160. 
pikir, kita tidak bisa mengatakannya, paling sedikit kita tidak mengetahuinya dengan pasti."22 Masalahnya adalah, untuk meminjam gagasan Ernst Bloch (18851977): "... manusia itu merindukan tempat, di mana dia belum pernah berada," dan topos keadilan merupakan salah satu tempat utama yang dirindukan manusia itu. ${ }^{23}$ Karena itu menjadi kodrat manusia, bahwa dia akan terus berusaha menggapai keadilan, betatapun "debatable"-nya konsep itu.

\section{Saudara Kembar Ketidaktertiban dan Ketidakadilan}

Karena kompleksitasnya, keadilan sebagai topos memang mudah sekali terperosok menjadi jurang ketidakadilan, seperti sudah diungkapkan oleh Marcus Tullius Cicero (Romawi, 106-43 SM): "Summum ius, summa iniuria,"24 (dalam keadilan tertinggi, bersemayamlah ketidakadilan tertinggi) sehingga menjadi penting untuk menelusuri penyebabnya. Sembilan belas abad kemudian, dalam observasi dari Karl Heinrich Marx (Jerman, 1818-1883), ketidakadilan itu lahir dari ketidak-setaraan sosial yang dihasilkan oleh Revolusi Industri yang disaksikannya di tempat pelariannya di Inggris.

Dalam Zur Kritik der politischen Ökonomie yang terbit di tengah maraknya Revolusi Industri (1859) yang membuahkan kapitalisme, Marx menjelaskan bahwa hubungan produksi yang berat sebelah merupakan basis (yang lebih terkenal sebagai "Unterbau") bagi struktur ekonomi yang nyata, di atas mana terbangun suprastruktur (Überbau) hukum dan politik, ${ }^{25}$ dan dengan demikian juga ditegakkan institusi negara. Hubungan produksi di zaman Marx yang tidak adil itu menghasilkan Überbau yang menindas mereka yang tidak berdaya dalam hubungan produksi, sehingga terjadilah konflik laten di antara mereka yang

${ }^{22}$ Kelsen, Id., hlm., 52; Rüthers, Id., hlm., 72.

${ }^{23}$ Dari bahasa Yunani, topoi: thema, tempat bersama, motif. Bloch, Ernst, Das Prinzip Hoffung, Band I-III, Frankfurt/Main: Suhrkamp, 1979. Kusumohamidjojo, "Seratus Tahun Ernst Bloch, Prinsip Pengharapan“, dalam: Sinar Harapan, 1985-07-10.

${ }^{24}$ Adagium ini berasal dari Marcus Tullius Cicero, Lat: dalam keadilan tertinggi yang dirumuskan oleh manusia, bersemayam juga ketidakadilan yang tertinggi, dikutip dari: Alfred Sellner, Latein im Alltag, Wiesbaden: VMA-Verlag, 1980, hlm., 115.

25 Marx, Karl, Zur Kritik der politischen Ökonomie (1859), Vorwort, dalam: https://de.wikipedia. org/wiki/Basis_und_\%C3\%9Cberbau, 22-06-2015. 
menghamba pada tataran Unterbau (infrastruktur) dan mereka yang menguasai Überbau (suprastruktur).

Hubungan sosial yang demikian itu sarat dengan pertentangan antar-kelas yang pada giliran berikutnya pasti bermuara dalam ketegangan laten jika bukannya konflik yang timbul-tenggelam, dan jika keadaan memungkinkan: pecah sebagai revolusi. Pola hubungan produksi itu nota bene masih merupakan tumpuan utama bagi bangunan struktur sosial yang industrial dalam abad ke-21. Akibatnya, dalam abad ke-21 kita belum dapat membebaskan diri dari jurang antara yang kaya dan umumnya menguasai proses produksi di satu sisi dan di sisi lain mereka yang terjebak dalam eksploitasi industrial dan terpaksa menghamba dalam proses produksi, sehingga di mana-mana mereka dihantui oleh "PHK" dan kemiskinan struktural yang menyertainya.

Untuk mengatasi ketidakadilan itu Marx mengajarkan bahwa struktur sosial harus dibongkar, supaya rakyat dibebaskan dari penindasan dan kesengsaraan. Untuk mencapai tujuan itu, kaum proletar atau rakyat yang tidak bermodal itu harus merebut infrastruktur produksi untuk kemudian mendirikan masyarakat tanpa kelas. Cita-cita ini tadinya hendak diwujudkan terutama melalui Uni Soviet (1921-1991) dan Republik Rakyat Tiongkok (1949-), namun gagal, karena dua sebab utama: Pertama, ternyata di kedua negara itu tetap berlaku juga kelas penguasa dan kelas yang dikuasai. Dan kedua: doktrin masyarakat tanpa kelas terbukti tidak mendatangkan kemakmuran dan dengan demikian membuktikan kegagalan sosialisme sebagai sistem ekonomi. Karena itu selekas bebas dari tirani Mao Zedong (1893-1976), dengan gesit Deng Xiaoping (19041997) melancarkan langkah strategisnya "Modernisasi Yang Empat"26 pada tahun 1978, yang faktual mengawinkan sistem politik sosialis dengan sistem ekonomi kapitalis. Uni Republik Soviet Sosialis bubar pada tahun 1991 dan digantikan oleh Republik Federasi Rusia yang juga membuka pintu bagi kapitalisme.

\footnotetext{
26 "Modernisasi Yang Empat" (Sì gè xiàndàihuà) meliputi modernisasi di bidang-bidang pertanian, industri, pertahanan serta sains dan teknologi, dari: The Four Modernizations, dalam: https://en. wikipedia.org/?title=Four_Modernizations, 25-06-2015.
} 
Kendati doktrin masyarakat tanpa kelas terbukti gagal, doktrin pertentangan antar-kelas Marx malahan menjadi semakin relevan, karena kapitalisme yang mendatangkan kemakmuran ternyata mempertajam ketidakadilan sehingga membina letusan ketidaktertiban dalam sekam. Joseph E. Stiglitz (1943-) adalah seorang ekonom Amerika yang sudah di awal abad ke-21 sangat jengkel dengan ketidak-setaraan sosial di sana, sehingga memelintir semboyan Revolusi Amerika dari "Of the people, by the people, for the people" dalam artikelnya menjadi "Of the $1 \%$, by the $1 \%$, for the $1 \%$." Dia mengemukakan konstatasi yang kemudian menjadi selebriti dengan istilah "the one percent":

"Dalam demokrasi kita, 1\% rakyat mengambil hampir seperempat dari pendapatan nasional ... dalam hal kekayaan ketimbang pemasukan, puncak yang $1 \%$ mengendalikan $40 \%$... dan sebagai akibatnya, puncak yang $1 \%$ itu memiliki rumah-rumah yang paling bagus, pendidikan yang paling baik, para dokter yang paling hebat, dan gaya hidup yang paling semarak. Tetapi ada satu hal yang tidak bisa dibeli dengan uang: yaitu suatu pemahaman bahwa nasib mereka juga terikat pada masalah, bagaimana yang 99\% lainnya itu hidup. Di sepanjang sejarah, ini merupakan urusan dari puncak yang $1 \%$ yang pada akhirnya menyadarinya, (namun) sangat terlambat." 27

Itulah yang saya maksudkan sebagai kekuatan ekonomi yang menjadi tumpuan dari supra struktur kekuasaan politik dan faktor penentu ketidaksetaraan sosial. Wanti-wanti dari Stiglitz dalam kalimat terakhir itu tidak hanya berlaku untuk Amerika Serikat, tetapi malahan lebih-lebih untuk Indonesia. Pengamatan dari Stiglitz itu kemudian diperlebar oleh Michael Sandel (Amerika, 1953-) yang menerbitkan Justice: What's the Right Thing to Do? (2009) sebagai kritik terhadap A Theory of Justice $(1970,1991)$ dari John Rawls. Sandel tidak membatasi diri dalam kritik ekonomi Stiglitz melainkan juga menyoal aspek-aspek ras, gender, masalah disabilitas, agama, dan sebagainya, dari ketidaksetaraan sosial. Dari buku Sandel saya menarik kesan bahwa dia sebenarnya mengajukan revisi terhadap kapitalisme untuk menjadi semacam "Kapitalisme Pancasila" - tanpa menyebut

27 Stiglitz, Joseph, "Of the $1 \%$, by the $1 \%$, for the $1 \%$ ", dalam: http://www.vanityfair.com/news/ 2011/05/top-one-percent-201105 (May 2011), 21-07-2015. Masalah ini pernah saya baca juga di The Economist, TIME dan Bloomberg Businessweek. 
istilah "Pancasila"- supaya kemakmuran disertai dengan kesetaraan sosial dan pemerataan kesejahteraan sehingga kehidupan bersama bisa menjadi semakin adil. ${ }^{28}$

Sesudah Marx, struktur kekuasaan dalam masyarakat antar kelas dijelaskan oleh Gaetano Mosca (Italia, 1858-1941) terutama dalam bukunya The Ruling Class (1884), di mana dia mendalilkan bahwa kapanpun, suatu negara dikuasai oleh suatu kelas penguasa, sehingga demokrasi itu hanya merupakan proses pergantian rezim penguasa dengan cara yang "lebih sopan" saja. ${ }^{29}$ Melalui apa yang dikenal sebagai "Teori Elitisme” itu Mosca seolah hendak menyatakan bahwa masyarakat tanpa kelas seperti yang diangankan oleh Marx itu adalah ilusi belaka. Jadi dalam satu hal itu secara historis terbukti bahwa Mosca lebih benar ketimbang Marx jika bukannya memang benar.

Dalam satu hal yang lain Marx dan Mosca sama-sama benar, yaitu bahwa kendati lebih berhasil dalam membawa kemakmuran ketimbang sistem sosialis, masyarakat industrial kapitalis itu memang cenderung tidak adil, meskipun mereka tidak menyatakan bahwa masyarakat pra-industrial itu niscaya adil sehingga boleh mengajak kita kembali ke zaman pra-industrial. Napak tilas seperti itu memang tidak mungkin karena berlawanan dengan rasionalitas evolusi manusia yang menghasilkan modernisasi yang terus-menerus. Karena itu Marx dan Mosca juga sama-sama benar mengenai ketidakadilan yang juga akan menghimpit masyarakat zaman kita yang sedang menuju tahap post-industrial, post-modern dan post-globalisation, baik di Indonesia maupun di kebanyakan manca negara.

Teori Marx yang memperlihatkan betapa struktur sosial masyarakat industrial cenderung menghasilkan struktur politik yang ditunjang oleh kekuatan ekonomi, pada sisi lain didukung oleh teori Mosca yang menyatakan bahwa kekuasaan politik itu selalu berada pada suatu golongan elite yang cenderung

\footnotetext{
${ }^{28}$ Sandel, Michael, Justice: What's the Right Thing to do? New York: Farrar, Straus \& Giroux, 2009.

${ }^{29}$ Mosca, Gaetano, The Ruling Class, New York/Toronto/London: McGraw-Hill, 1939 (pertama kali terbit dalam tahun 1884 dengan judul (Italia) Elementi di scienza politica), hlm., 50, 58, dan 395.
} 
tidak menguntungkan bagi rakyat banyak. Padahal, seperti didalilkan oleh Max Weber (Jerman, 1864-1920), politik itu adalah memang interes untuk merebut, mempertahankan dan menggunakan kekuasaan, ${ }^{30}$ untuk tujuan apa saja: bisa baik maupun tidak baik untuk kehidupan bersama.

Dengan begitu selalu ada risiko bahwa kekuasaan politik diselenggarakan untuk mendatangkan manfaat yang parsial dengan cara apapun, termasuk juga dalam demokrasi yang hanya alih-alih melibatkan rakyat banyak dalam pembuatan keputusan untuk memastikan keselamatan dan kesejahteraan bersama. Apa yang dialami oleh rakyat Indonesia sejak Reformasi 1998 membuktikan konstatasi itu. Dalam hingar-bingarnya proses demokratisasi sejak reformasi, kita tidak menyadari bahwa demokratisasi politik tidaklah niscaya berarti juga demokratisasi ekonomi, seperti yang sudah didalilkan oleh Jürgen Habermas: "kekuasaan bisa didemokratisasi, tetapi uang tidak bisa."31 Di ranah politik bisa berlaku kaidah "satu orang, satu suara", tetapi di pasar modal ada orang yang bisa memiliki jutaan saham, dan bisa juga banyak orang tidak memiliki saham apapun.

Di segala zaman dan tempat, memang selalu terdapat segelintir orang yang seperti dilahirkan dengan bakat-bakat untuk selalu lekat dengan kekuasaan politik. Padahal seperti ditekankan oleh Hannah Arendt, kekuasaan politik selalu digoda oleh dorongan untuk menjadi tidak rasional, karena bagaimanapun juga kekuasaan itu selalu merupakan hasrat untuk menguasai, baik dengan cara dan tujuan yang "baik" maupun dengan cara dan tujuan yang "tidak baik".32 Kerepotannya adalah: soal baik dan buruk itu pada akhirnya merupakan soal selera buatan manusia belaka, seperti dinyatakan oleh Friedrich Nietzsche (Jerman, 1844-1900). Pada giliran berikutnya kekuasaan politik yang tidak

\footnotetext{
${ }^{30}$ Weber, Max, Politik als Beruf, Berlin: Duncker \& Humblot, 1926, hlm., 8-9.

${ }^{31}$ Jürgen Habermas, Die postnationale Konstellation: Politische Essays, Frankfurt/Main: Suhrkamp, 1998: 119-120, "Nur die Macht lässt sich beispielsweise demokratisieren, nicht das Geld."

${ }^{32}$ Hannah Arendt, The Human Condition, The University of Chicago Press, (1956) 1989, hlm., 200204.
} 
rasional cenderung menghasilkan absolutisme dan despotisme yang dengan sendirinya menghasilkan hukum yang tidak adil. ${ }^{33}$

Kaum penguasa absolut dan despotik nyaris sepenuhnya memenuhi gambaran dari Han Feizi (Tiongkok, 280-233 SM) yang menyatakan bahwa karakter dasar manusia pada dasarnya adalah jahat ${ }^{34}$ dan Niccolo Machiavelli yang kemudian menyatakan bahwa manusia itu cenderung berbuat jahat jika tidak dipaksa untuk berbuat baik. ${ }^{35}$ Dalam sejarah memang tidak kurang penguasa-penguasa seperti itu yang tidak terbatas pada Louis XIV (Prancis, 16381715) yang dalam abad ke-17 menyatakan dengan angkuh: "L'État, c'est moi" (negara adalah saya); Perdana Menteri Iosif Vissarionovich Stalin (Uni Soviet, nama aslinya: Iosif Vissarionovich Dzhugashvili, 1878-1953) yang pernah bilang kepada Perdana Menteri Winston Churchil (Inggris, Sir Winston Leonard SpencerChurchill, 1874-1965): jika ada satu orang yang meninggal, itu adalah tragedi, tetapi jika ada seribu orang yang mati, itu adalah statistik; ${ }^{36}$ atau Perdana Menteri Saloth Sar (Kamboja, lebih terkenal sebagai Pol Pot, 1925-1998) ${ }^{37}$ yang membantai 1,4 juta rakyatnya sendiri untuk mengembalikan Kamboja ke zaman pra-agraris. $^{38}$ Jadi, jika orang berkuasa, hiduplah kecenderungannya untuk menguasai orang lain, dan jika hasrat itu tidak dikendalikan, dia akan berkembang

33 Friedrich Nietzsche, "Zur Naturgeschichte der Moral", dalam: Jenseits von Gut und Böse: Vorspiel einer Philosophie der Zukunft, (1886) München: Goldmann Verlag, 1996, hlm., 76-93, khususnya. hlm., 77, 80, 83-84, 91-92. Seorang despot adalah penguasa yang berlaku sesuka-sukanya.

34 Kusumohamidjojo, "Han Feizi's Political Philosophy and Today's China”, dalam: MELINTAS: An International Journal of Philosophy and Religion, Department of Philosophy, Parahyangan University, Bandung - Indonesia, ISSN 0952-0089, Vol. 25 No. 1, April 2009, pp. 45-56.

35 Fung Yulan, A Short History of Chinese Philosophy, New York etc: The Free Press, [1948], hlm., 159-161; Niccolo Machiavelli, Discorsi, Gedanken über Politik und Staatsführung, (dari versi Italia, Discorsi Sopra la Prima Deca di Tito Livio, 1513-1522, oleh Rudolf Zorrn), Stuttgart: Alfred Kröner Verlag, 1977, hlm., 17-18.

${ }^{36}$ Kutipan itu diambil oleh David McCullough untuk bukunya The life of Harry S. Truman, dari buku The Time of Stalin: Portrait of Tyranny yang ditulis oleh Anton Antonov-Ovseyenko, halaman 278. Lihat: http://en.wikiquote.org/wiki/Joseph_Stalin, Retrieved from http://en.wikipedia.org/w/ index.php?title=Joseph_Stalin\&oldid=1467097, 21-09-2012.

37 Nama perang ini merupakan singkatan dari "Politique potentielle" yang dijulukkan kepadanya oleh para pemimpin RRT di zaman Mao Zedong, dari Pol Pot, dalam: https://en.wikipedia.org/wiki/Pol_Pot, 13-08-2015. Saloth Sar memang pernah sekolah di Prancis.

${ }^{38}$ Ngor, Haing \& Roger Warner, Survival in the Killing Fields. New York: Carroll \& Graf, 2003; juga: "Killing Fields", dalam: Wikipedia, https://en.wikipedia.org/wiki/Killing_Fields, 08-08-2015. 
menjadi nafsu yang absolut atau malahan despotik, paling sedikit dengan membenarkan pikirannya sendiri, baik dengan cara yang mentah dalam otokrasi maupun sopan dalam demokrasi.

Di zaman post-industrial nafsu berkuasa itu mengalami pengendalian melalui impersonalisasi dan menjelma sebagai sistem, baik yang demokratis maupun yang otoriter. Dalam sistem yang tidak demokratis kekuasaan politik itu dimonopoli oleh suatu oligarki dan tampil sebagai feodalisme modern. Di negaranegara yang demokratis kekuasaan politik ditransfer kepada institusi-institusi kenegaraan yang seyogianya menjadi pagar terhadap absolutisme dan despotisme. Namun tetap saja di banyak negara yang demokratis, apalagi yang baru melek rasionalitas, institusi-institusi kenegaraan yang alih-alih mewakili aspirasi rakyat banyak itu dengan satu dan lain cara mengalami pemelintiran untuk lantas dikuasai oleh suatu besaran kekuasaan yang menggaris-bawahi kepentingannya sendiri, dan dengan demikian secara samar-samar tampil sebagai absolutisme dan bisa juga sebagai despotisme oligarkis yang baru. ${ }^{39}$

Dengan begitu pemilihan umum yang merupakan tulang punggung demokrasi itu sebenarnya hanya merayakan pergantian oligarki kekuasaan, baik di Indonesia, maupun di Amerika Serikat atau di negara-negara demokratis yang lain. Tidak bisa dihindarkan, bahwa dengan merujuk kepada Han Feizi dan Machiavelli, oligarki politik yang absolut dan despotik itu, baik yang modern tetapi apalagi yang kuno, akan lebih memantapkan oligarki ketidakadilan yang dapat mereka nikmati buahnya. Itulah pangkal dari kekalahan hukum terhadap korupsi di Indonesia yang berlarut-larut, karena memang ada kalangan yang secara ekonomis menjadi semakin kuat karena korupsi dan semakin menikmati buahnya, seperti sudah dikonstatasi oleh Mosca. ${ }^{40}$ Jika harga sebidang tanah di kawasan SCBD di Jakarta sekarang sudah 250 juta rupiah per meter perseginya, dan ternyata masih ada yang sanggup membelinya kecuali rakyat, kita mendapatkan

\footnotetext{
${ }^{39}$ Kusumohamidjojo, "Law and mafia democracy", dalam: The Jakarta Post, Monday, January 30, 2012.

${ }^{40}$ Supra no. 29, hlm., 135.
} 
kenyataan yang membenarkan teori Han Feizi, Machiavelli, Marx, Mosca dan Vilfredo Pareto (Italia, 1848-1923) sekaligus.

Kita tahu dari sejarah bahwa absolutisme dan despotisme Louis XIV menghidupkan ketidakadilan yang masif dan membuat rakyat Prancis menderita sengsara yang luar biasa. Ketidakadilan yang dipelihara itu lantas menghasilkan Revolusi Prancis yang meletus pada tahun 1789 dan melahirkan Republik Prancis yang pertama. Terjadilah "Umwandlung der Werte" (Deu: penjungkir-balikan nilainilai) seperti yang kerap disinggung oleh Presiden Soekarno (nama aslinya: Kusno Sosrodihardjo, 1901-1970), dan kemudian menggelinding ke Asia dan Afrika untuk membongkar ketidakadilan dari kolonialisme, seperti yang juga dijangkarkan dalam Pembukaan UUD 1945.

Seperti banyak konstitusi lainnya, juga UUD 1945 tadinya hendak mengibaskan hukum yang tidak adil yang bertumpu pada kekuasaan yang tidak rasional dan rentan menghasilkan ketidaktertiban dan kesengsaraan, serta menggantikannya dengan hukum yang adil untuk mendatangkan perdamaian dan kesejahteraan dalam kehidupan bersama. Namun hasilnya antara lain adalah "fenomena SCBD" yang membuat saya teringat pada pembicaraan perpisahan dengan promotor utama saya di Jerman pada tahun 1982, yang mengatakan dengan dingin: "Apa yang terjadi di negara anda itu cuma pergantian kekuasaan dari kaum kolonialis kulit putih kepada kaum kolonialis kulit coklat." Tadinya saya ingin protes pernyataan itu, tetapi tidak punya bahan yang cukup untuk membantahnya. Sekarang menjadi giliran kita semua untuk menyanggah, bahwa konstatasi dari Gerhard Ritter (Gerhard Friedrich Ritter, 1915-2013) itu adalah tidak benar.

\section{Kekuasaan, Rasionalitas, Hukum}

Hukum seperti yang hendak ditegakkan oleh UUD 1945 adalah pranata canggih yang bertujuan mengatur perilaku manusia dalam kehidupan bersama supaya kehidupan bersamanya itu dapat berlangsung dengan tertib dan adil. 
Pengaturan itu diharuskan karena secara alamiah manusia itu berkemampuan untuk melakukan pilihan dan membuat keputusan dalam tiga kategori utama:

a. kategori logis: memilih yang benar ketimbang yang salah;

b. etis: memilih yang baik ketimbang yang buruk; dan

c. estetis: memilih yang bagus ketimbang yang jelek.

Di antara ketiga kategori itu, kategori logis adalah kategori yang berlaku universal dan kapan saja, karena seperti sudah dikemukakan oleh Aristoteles kaidah logik itu berlaku di segala zaman dan di segala tempat bagi manusia yang memiliki apa yang oleh Immanuel Kant 22 abad kemudian disebut sebagai "gesunde Menschenvernunft" (akal sehat manusia). Kategori etis dan kategori estetis banyak tunduk pada selera manusia yang berubah dari zaman ke zaman dan berbeda dari tempat yang satu ke tempat lain seperti sudah diingatkan oleh Nietzsche. Karena merupakan kategori yang paling universal dan langgeng di antara berbagai kecakapan manusia, kategori logis yang menjadi hakikat dari rasionalitas seharusnya menjadi tumpuan utama dari hukum.

Rasionalitas hukum mengharuskan manusia untuk menyelenggarakan kehidupan bersama tidak berdasarkan hukum rimba, atas dasar mana makhlukmakhluk saling memangsa atas dasar siapa kuat dia menang. Berujarlah Aristoteles: "hanya para dewa dan hewan yang tidak memerlukan kehidupan bersama,"41 karena para dewa tahu segalanya, sedangkan hewan tidak tahu apapun, sehingga keduanya tidak bisa berbuat salah dalam kehidupan bersama mereka. Manusia itu selalu "kenyang tanggung" tidak serba tahu, maka bisa berbuat salah, sehingga kodratnya yang merupakan "anthropos physei politikon zoon" (dari alamnya manusia adalah makhluk politik) ${ }^{42}$ mengharuskannya untuk saling mengatur perilaku masing-masing dalam kehidupan bersama. Kompleks tatanan yang saling mengatur itu kita sebut "hukum".

${ }^{41}$ Aristoteles, Politika, sebagaimana dikutip oleh Arno Baruzzi dalam Rausch, Heinz (Ed.). Politische Denker, Band I, II, III, München: Bayerische Landeszentrale für Politische Bildungsarbeit, 1977, hlm., 33; Zippelius, Reinhold, Geschichte der Staatsideen, München: Beck, 1980, hlm., 19.

42 Skirrbek, Gunnar \& Nils Gilje, Geschichte der Philosophie, Eine Einführung in die europäische Philosophiegeschichte, Band I, München: Suhrkamp, [1987] 1993, hlm., 142. 


\section{Compang-Campingnya Dunia Hukum Dan Hakim}

Marcus Tullius Cicero sudah menyadari bahwa hukum itu mengalami personalisasi dalam diri para pejabat publik, terutama para hakim yang pada akhirnya memutuskan mana yang sesuai dari yang tidak sesuai dengan hukum. Dia merumuskan korelasi antara hukum dan hakim itu begini: hukum adalah pejabat (hakim) yang membisu, sedangkan pejabat (hakim) sebaliknya adalah hukum yang bersabda. ${ }^{43}$ Dalam sepanjang sejarahnya, manusia mengharapkan bahwa simbiosis di antara kedua subjek itu membawa keadilan, tetapi dalam menjelajahi abad ke-21 nampaknya mayoritas masyarakat dunia justru akan semakin menderita ketidakadilan. ${ }^{44}$ Tendensi itu disebabkan oleh fenomena: kerja hukum itu selalu tertinggal dari dinamika masyarakat, yang sudah dikenal oleh orang Belanda yang punya peri bahasa: "Het recht is een hekken sluiter," (hukum itu adalah penutup pintu pagar (masyarakat)).

Itulah sebabnya sejarah memperlihatkan, bahwa keadilan kerap kali tidaklah merupakan tujuan utama yang niscaya hendak dicapai oleh suatu kehidupan bersama. Keadilan, apalagi keadilan yang sempurna, andaikata pun bisa dijadikan tujuan akhir dari kehidupan bersama, sebelumnya selalu sudah didahului oleh berbagai macam tujuan antara lainnya, seperti misalnya kemerdekaan, kemakmuran, kesetaraan, dsb. Kenyataan itu merupakan konsekuensi dari paradigma kebudayaan yang dinamis, sehingga masyarakat senantiasa menggeser skala prioritas tujuan bersama mereka.

Bila difahami dalam kerangka Freudian, pergeseran-pergeseran itu disebabkan oleh kegalauan persisten manusia yang bersumber dari tiga sebab: 1) sifat degeneratif fisiknya (yang tidak terbendungkan), 2) kekuatan yang dahsyat dari alam, dan 3) hubungan antar-manusia yang rawan konflik. Sigmund Freud (Austria, 1856-1939) malahan mengidentifikasi sepotong konstitusi psikis dalam

\footnotetext{
43 Dikutip dari Antoon Vloemans, Politeia, Geschiedenis van de sociaal politieke filosofie, Den Haag: Kruseman's, 1971, hlm., 59, yang merujuk pada karya Cicero: De Legibus, I, 2.

${ }^{44}$ Kusumohamidjojo, Filsafat Hukum: Problematik Ketertiban yang Adil, Jakarta: Grasindo, 2004: Para 10.3.
} 
diri manusia yang tidak tertaklukkan sebagai biang keladi dalam hubungan antarmanusia yang sarat dengan potensi derita itu, yaitu "sang ego". 45

Dalam pergeseran skala prioritas itulah keadilan yang ideal terus menerus digeser ke ujung skala yang lebih jauh dan semakin jauh. Kenyataan dalam masyarakat menunjukkan, bahwa keadilan itu menjadi perkara yang semakin terlalu abstrak untuk harus dicapai sebagai tujuan yang seolah-olah bisa dijangkau dalam hidup ini. Berujarlah Karl Popper dalam bukunya yang kesohor The Open Society and its Enemies:

"The attempt to make heaven on earth invariably produces hell. It leads to intolerance. It leads to religious wars, and to the saving of souls through the inquisition." 46

Sedangkan Bernd Rüthers menyatakan: hukum yang ditujukan untuk mencapai keadilan itu pada akhirnya adalah hasil perumusan manusia, jadi bisa saja salah, sehingga tidak mungkinlah kita mengharapkan keadilan sempurna di dunia ini. Barang siapa bersikeras menghendaki keadilan yang sempurna, dia harus mencarinya di alam yang lain. ${ }^{47}$

Ketidak-sempurnaan keadilan yang niscaya itu menancap sebagai pasak masalah yang kerap kali lebih besar daripada tonggak penegakan hukum di tangan para hakim: yaitu moralitas sosial yang menjadi inti dari segala upaya penegakan hukum. Dalam semua masyarakat yang normal, pasak itu berada dalam diri para hakim yang diandalkan oleh masyarakat sebagai "benteng keadilan yang terakhir". Karena itu, jika benteng itu membusuk karena korupsi dan segala macam perbuatan manusiawi yang sub-human, tiba juga saatnya untuk

\footnotetext{
45 Sigmund Freud, Das Unbehagen in der Kultur, Frankfurt/Main: Fischer Taschenbuch Verlag, [1930] 2007: 43. Lihat juga John Deigh, "Freud's Later Theory of Civilization: Changes and Implications", dalam Jerome Neu, (ed.), The Cambridge Companion to Freud, Cambridge University Press, [1991] 1999, 287-308, hlm., 291.

46 Sir Karl Popper, "Oracular Philosophy and the Revolt against Reason", dalam: The Open Society and Its Enemies, Princeton UP [1945] 1971: Vol. 2, Ch. 24.

47 Bernd Rüthers, Rechtstheorie, München: CH Beck, 2005, hlm., 2-3.
} 
meragukan pencapaian tujuan dari suatu negara. Bahkan Machiavelli menulis: negara itu adalah sia-sia jika tidak berhasil menegakkan keadilan. ${ }^{48}$

Para hakim yang memegang kekuasaan yudisial menegakkan hukum dan menghukum pelanggaran terhadapnya jadi berperanan menentukan dalam pencapaian tujuan dari suatu negara. Di zaman kekuasaan absolut, kekuasaan trias politica biasa berada dalam satu tangan. Tetapi kita tahu bahwa Montesquieu (Prancis, Charles-Louis de Secondat, Baron de La Brède et de Montesquieu, 16891755) memecahkan konsentrasi trias politica itu untuk melindungi rakyat banyak dari kesewenang-wenangan.

Dengan begitu kekuasaan yudikatif seharusnya merupakan penjaga pintu gerbang belakang negara yang mencegat segala tindakan yang bertentangan dengan hukum positif, yang teorinya memang menghendaki bahwa tidak ada ketidakadilan yang bisa lolos dari pintu gerbang belakang negara itu. Kendati demikian, kenyataan yang sebenarnya kerap kali mengecoh siapa saja, terutama kalangan rakyat yang jauh dari pusat kekuasaan, baik secara geografis, apalagi secara struktural.

Penyelewengan itu bahkan masih bisa terjadi di negara-negara yang sudah banyak menghormati rule of law, apalagi di negara-negara yang baru belajar menjadi modern. Hal itu disebabkan oleh struktur dari kekuasaan yudikatif yang diselenggarakan melalui badan peradilan sebagai pelaksana kekuasaan kehakiman itu ujungnya berada di tangan para hakim yang pada akhirnya adalah manusia biasa juga. Ronald Dworkin (Amerika, 1931-2013) mengamati dengan cermat, bahwa seorang hakim sebagai warga negara biasa dalam kenyataannya membuatnya juga rawan terhadap penyimpangan. ${ }^{49}$ Semakin tidak tertib keadaan organisasi suatu pemerintah, semakin tinggilah penyimpangan itu, dan semakin meningkat juga tingkat kerawanan itu, apalagi jika ditimpali dengan budaya (kebiasaan berperilaku) korupsi dalam banyak masyarakat yang bersangkutan.

\footnotetext{
48 Niccolò Machiavelli: Il Principe.

49 Ronald Dworkin, “Integrity in Law”, dalam: Law's Empire, Harvard UP, 1986, hlm., 225-276.
} 
Dworkin yang sempat dijuluki sebagai "Filosof Penderitaan" dengan lugu mengharapkan bahwa para hakim itu bermoral di atas rata-rata warga negara biasa, supaya para hakim menafsirkan undang-undang "dengan benar", dan atas dasar itu lalu membuat keputusan yang benar juga. Dalam kenyataan, harapan itu kerap kali berujung hampa dan bermuara dalam keputusan asal jadi yang akar sebenarnya tertanam dalam struktur dan membawa penderitaan dari korban ketidakadilan. Kata pengacara Henry Yosodiningrat dalam acara Mata Najwa belum lama ini: "Banyak sekali keputusan hakim yang (isinya) bodoh,"50 dan fenomena itu tidak hanya terbatas di Indonesia.

Kalau sudah begitu, lalu bagaimana dan apa yang harus kita lakukan terhadap kenyataan seperti yang saya lampirkan di sini, yang nota bene hanya sedikit di antara banyak sekali keanehan yang dihasilkan oleh badan peradilan, tidak hanya di Indonesia, tetapi juga di berbagai negara lain? Berikut ini adalah sedikit dari banyak fakta pahit compang-campingnya praktik kehakiman yang membenarkan konstatasi dari Popper dan Rüthers yang saya ambil dari India, Indonesia, Amerika Serikat dan Uni Eropa.

Pengamatan atas praktik peradilan di India pada tahun 2005 bisa sungguhsungguh membuat putus asa para pencari keadilan: hanya ketika itu saja terdapat 20 juta kasus tertunggak pada tingkat pengadilan negeri, 3,2 juta kasus pada tingkat pengadilan banding, dan 20.000 kasus pada tingkat mahkamah agung. ${ }^{51}$ Belum lagi berbagai "kecelakaan hukum” karena ketidakadilan yang dihasilkan dari proses hukum yang asal jadi.

Saya tidak mempunyai data mengenai produktivitas badan peradilan di Indonesia, tetapi contoh berikut ini hanya dua butir dari segunung vonnis hakim yang "tidak pakai hati”: "Mencuri 3 Buah Kakao, Nenek Minah Dihukum 1 Bulan 15 Hari,"52 atau: "Pencuri Sandal Jepit 5 Tahun Penjara, Koruptor 1,5 Tahun."53

\footnotetext{
50 Mata Najwa, Metro TV, 20:35, 08-08-2015.

51 Oberdorf, Jason, “Unclogging the Courts“, dalam Newsweek, 18 July 2005, hlm., 32-33. Saya tidak mempunyai data tentang Indonesia.

52 detikNews, Kamis 19 Nov 2009, 15:24 WIB, dalam: http://news.detik.com/berita/1244955/ mencuri-3-buah-kakao-nenek-minah-dihukum-1-bulan-15-hari, 24-06-2015.
} 
Atau lebih parah lagi: bukan sekali dua kali terjadi di Amerika Serikat, bahwa orang menjalani eksekusi hukuman mati, dan kemudian melalui pengujian DNA terbukti bahwa terpidana yang sudah dibunuh itu ternyata tidak bersalah. ${ }^{54}$

The European Convention on Human Rights sejak tahun 1950 merumuskan dan menjamin hak asasi manusia dan kebebasan-kebebasan mendasar di Eropa. Sejalan dengan itu The European Court of Human Rights merupakan satu-satunya pengadilan internasional yang dapat menerima keluhan perorangan. Pada tahun 2007 Pengadilan ini menjatuhkan 1.503 keputusan, tetapi pada tahun 2010 Pengadilan ini ditumpuki dengan 120.000 kasus yang tak tertangani. Dengan cara begini, The European Court baru akan menyelesaikan pekerjaannya (ketika itu) dalam waktu 47 tahun. Belum lagi dihitung perkara-perkara yang masuk kemudian. Ini adalah suatu tragik bagi penderita pelanggaran hak asasi manusia di Eropa, belum lagi di kawasan lain di dunia yang keadaannya lebih parah lagi.

Fakta historis dari compang-campingnya hukum dan hakim itu menjadi sumber dari suatu peribahasa Jerman kuno: "Vor Gericht und auf hoher See ist man in Gottes Hand" (Di depan pengadilan dan di samudra luas, nasib orang ada di tangan Tuhan), ${ }^{55}$ yang mencerminkan betapa mahakuasanya para hakim dan tidak berdayanya rakyat. Menjadi semata-mata realistik belaka untuk menyatakan, bahwa untuk kebanyakan penderita ketidakadilan di dunia memang tipis sekali harapan untuk memperoleh pemulihan, dan apalagi keadilan. Memang kejam untuk berkesan, bahwa untuk kebanyakan penderita ketidakadilan, orang hanya bisa terima nasib. Tetapi untuk sebagian besar kasus, memang begitulah kenyataannya.

Saya teringat pada "strategi fatalis" dari Zhuangzi yang seorang filosof Tiongkok kuno aliran Dao (370-301 SM) bagi para penderita ketidakadilan yang mengalami nasib seolah tanpa harapan. Dia menganjurkan untuk menghadapi

\footnotetext{
53 Tunas Bangsa, 9 Januari 2012, dalam: http://www.tubasmedia.com/pencuri-sandal-jepit-5tahun-penjara-koruptor-15-tahun/, 24-06-2015.

54 Death penalties exonerated, dalam: http://www.deathpenaltyinfo.org/innocence-list-thosefreed-death-row, 21-11-2014.

55 Otfried Höffe, Gerechtigkeit: Eine philosophische Einführung, München: C.H. Beck, 2010, hlm., 53.
} 
situasi jelek seperti itu dengan sikap wúwèi (diam, tidak berbuat) yang konsekuen: "bersikaplah seolah-olah kau adalah manusia yang sama sekali tidak berguna, dan terimalah nasibmu."56 Alih-alihnya adalah, dengan demikian orang tidak akan terlalu menyadari dan merasakan nasib sial yang dialaminya.

Ada kemungkinan besar bahwa kita tergolong orang-orang yang merasakan bahwa ada begitu banyak ketidakadilan di kota di mana kita hidup, di negara kita, di dunia kita. Sebagian dari ketidakadilan itu bisa kita derita juga, dengan tingkat intensitas yang berbeda-beda. Sebagian di antara kita mungkin bersikap masih dapat melanjutkan hidup dengan ketidakadilan yang dideritanya sambil berperspektif realistik, bahwa begitulah keadaan dunia, dan tidak bisa lain. Sebagian lain bergulat untuk mengatasi ketidakadilan yang dideritanya atau yang diderita oleh orang-orang yang hendak dibelanya, dan berjuang untuk membuat keadaan sekeliling menjadi lebih adil.

Sebagian yang lain lagi menyimpan kemarahan yang nyaris meledak karena tidak sanggup menerima ketidakadilan yang menhunjam dan melukai eksistensi dirinya. Masih ada sebagian lain lagi yang mengalami ketidakadilan yang parah, namun memilih untuk menyerah karena merasa tidak sanggup lagi melakukan perlawanan. Golongan yang terakhir ini tanpa sadar menjalankan nasihat dari Zhuangzi: bersikap pasrah, yang nota bene merupakan suatu konsep yang banyak dianut di Jawa, meskipun menurut pengamatan saya, sebagian besar umat manusia memang memilih jalan ini karena terpaksa.

Masalahnya adalah, meskipun nasihat Zhuangzi dijalankan tanpa sadar oleh bermiliar orang nestapa di dunia, dia sebenarnya berlawanan dengan logika kebanyakan "orang biasa", yang akan mencoba untuk tidak tinggal diam dan melakukan apa saja, kalau bisa termasuk revolusi, untuk membangun tatanan sosial yang lebih adil, jika mereka memandang keadaan sudah tidak tertahankan lagi. Mereka yang tidak terlalu revolusioner, yang memang selalu ada juga, akan memilih jalan damai "parlementer" yang lebih evolusioner namun cenderung

56 Liu JeeLoo, An Introduction To Chinese Philosophy: from Ancient Philosophy to Chinese Buddhism, Malden MA: Blackwell, [2006] 2008, hlm., 172-173. 
tidak efisien, seperti kebanyakan orang di Eropa, Jepang, atau Amerika. Presiden Obama misalnya mengakui inefisiensi dari sistem politik Amerika Serikat: ${ }^{57}$

"Demokrasi dari bangsa 300 juta orang bisa bising serta morat-marit dan rumit. Kita punya pendapat masing-masing. Masing-masing dari kita punya kepercayaan yang mendalam. Dan tatkala kita menjalani masa-masa yang berat, tatkala kita membuat keputusan-keputusan besar sebagai negara, pastilah terjadi gereget, terjadi kontroversi."

Logislah, jika kontroversi itu acapkali membuat jalan untuk merubah ketidakadilan menjadi keadilan, atau untuk membangun kehidupan bersama yang lebih adil, menjadi jalan yang sungguh-sungguh merepotkan sehingga menempatkan aspirasi keadilan itu semakin jauh panggang dari api.

Semakin kompleks suatu masyarakat, semakin kompleks juga persepsi mengenai keadilan, dan semakin sukar juga bagi orang banyak untuk sefaham mengenai keadilan, serta semakin tipis harapan untuk mendapatkan keadilan. Itulah sebab utama, mengapa Will Kymlicka melihat tugas utama filsafat politik adalah untuk mencari jalan keluar dari ketidakadilan dengan membangun semacam ideosinkretisme yang mengambil segala yang baik dari sana-sini:

"A successful theory of justice, therefore, will have to accept bits and pieces from most of the existing theories,"

Suatu teori keadilan yang sukses karenanya akan harus mengambil sedikit dari sana dan sedikit dari sini dari teori-teori yang ada. 58

Kendati demikian maksud baik Kymlicka itu akan berbenturan dengan kebutuhan nyata dunia akan jalan keluar yang cepat dan efektif. Karena itu ketimbang mengejar keadilan, tujuan yang lebih real dari hukum sebenarnya adalah ketertiban, kendati kebanyakan orang kerap tidak (mau) mengakui kenyataan ini secara terang-terangan. Semakin kompleks suatu masyarakat, akan

57 Barack Hussein Obama, Pidato kemenangan untuk masa jabatan kedua, 06 November 2012, Transcript: Obama's victory speech, http://politicalticker.blogs.cnn.com/2012/11/07/ transcript-obamas-victory-speech/, 14-01-2013.

58 Kymlicka, Will, Contemporary Political Philosophy: An Introduction, Oxford UP, [1990] 1997, hlm., 3. 
semakin dibutuhkan ketertiban lebih dulu. Bahkan juga seandainya acapkali dia ditegakkan dengan di sana-sini mengorbankan keadilan. 59

Banyak masyarakat bisa tetap tegak dengan bertumpu pada ketertiban, sambil masih terus memperdebatkan ketidak-sefahaman mengenai keadilan secara berlanjut. Sebaliknya tidak ada masyarakat yang bisa tegak karena tidak tertib dan karenanya tidak sempat memperdebatkan konsep keadilan, sementara upaya untuk mencapai keadilan - yang seadanya, apalagi yang sempurna - tanpa melalui ketertiban itu adalah ilusi belaka. Indikasi ini bisa kita dapatkan dari observasi terhadap tingginya tingkat resepsi rakyat Rusia pasca runtuhnya Uni Soviet bagi gaya pemerintahan Vladimir Putin (1952-) yang cenderung bergaya Soviet dan bernuansa otoriter namun menertibkan, ketimbang gaya pemerintahan Boris Yeltsin (1931-2007) yang bergaya Perestroika dan bernuansa liberal namun membawa khaos. ${ }^{60}$

\section{Segi Tiga Serangkai: Ketertiban, Kemakmuran dan Keadilan}

Uraian di atas sebenarnya hendak memaparkan, betapa kapitalisme yang bertumpu pada ketertiban dan mendatangkan kemakmuran itu potensial mempertajam ketidakadilan karena ketidak-setaraan yang menyertainya. Compang-campingnya sistem hukum dan kinerja kebanyakan hakim hanya memperberat masalah itu.

Ketika kemerdekaan dari dua orang atau dua bangsa bertemu, seharusnya di situ juga terjadi kesetaraan derajat (equality), tetapi tidak mungkin persamaan (equation). Pada garis demarkasi itulah konsep kesetaraan, dan bukannya persamaan, mendapatkan relevansinya sebagai dasar bagi keadilan yang proporsional. Dalam kenyataan tidaklah pernah ada persamaan, sehingga keadilan tidaklah mungkin demi persamaan.

59 Kusumohamidjojo, Filsafat Hukum, Id., Bab 610, mengutip Apeldoorn, L.J. van, Pengantar Ilmu Hukum, Jakarta: Noordhoff-Kolff, 1960.

60 Kusumohamidjojo, Filsafat Kebudayaan, Proses Realisasi Manusia, Jalasutra, Yogyakarta, 2009, Bab 07.2. 
Manusia sudah terjerumus dalam ketidak-samaan, tatkala yang satu lahir sebagai anak petani, sedangkan yang lain lahir sebagai anak presiden. Seorang petani tradisional di pulau Jawa yang karena berbagai sebab tidak berhasil menyelesaikan pendidikan dasar tidak bisa memahami kebutuhan hidup yang meluap dan seperti tak ada kenyangnya dari seorang raja real estate di Jakarta atau raja kapal di Hongkong.

Asas persamaan cuma mengatakan bahwa alam itu memberikan kesempatan yang sama kepada setiap orang untuk merealisasikan dirinya, dan memang hanya sebatas itu jugalah makna dari adagium "men are born equal" seperti yang diguratkan dalam Konstitusi Amerika Serikat. Tetapi justru Amerika Serikat bahkan setelah berdiri lebih dari dua abad semakin digerogoti oleh ketidak-setaraan (unequality) sebagaimana sering dikeluhkan oleh Presiden Barack Obama. Obama menyadarinya sebagai bahaya laten, sehingga dia bersikeras untuk antara lain meloloskan undang-undang tentang kesehatan bagi setiap orang Amerika, supaya warga-negara Amerika yang tidak berhasil meraih kesempatan yang sama dalam kompetisi catch-as-catch-can, tetap terlindungi kebutuhan dasar hidupnya.

Jika fenomena ketidaksetaraan sosial yang tidak jarang menjadi biang keladi dari ketidakadilan sosial pada tingkat nasional ini kita proyeksikan ke tingkat global, kita akan mendapatkan gambaran yang tidak berbeda, seperti yang dilaporkan oleh Ulrich Beck (1944-2015). Beck yang mengumumkan dunia abad ke-21 sebagai "risk society"mencatat pada tahun 2003, bahwa hanya ada kira-kira 350 miliarder (Dollar Amerika) di dunia yang menikmati separuh dari GDP dunia yang besarnya adalah USD79,39 triliun. ${ }^{61}$ Dunia sisanya dipenuhi oleh orangorang miskin sampai sangat miskin yang 6,8 miliar jumlahnya yang harus berbagi sisa dari apa yang dimiliki oleh 350 orang itu. ${ }^{62}$

61 Data IMF, November 2012. Untuk perbandingan, ukuran ekonomi Amerika Serikat ketika itu adalah lebih dari USD15 triliun.

62 Beck, Ulrich, What is Globalization?, Cambridge: Polity, 2003: 153. Lihat juga: http://en.wikipedia.org/wiki/World_population, Retrieved from http://en.wikipedia.org/w/ index.php?title=World_population\&oldid=516918221, 11-10-2012. 
Konfederasi Swiss itu penduduknya cuma sekitar 7,8 juta orang yang hidup di wilayah seluas $41.285 \mathrm{~km}$ persegi namun mempunyai GDP pc sebesar USD67.384 per tahun yang bahkan lebih tinggi dari GDP pc Amerika Serikat yang USD 48.442 (data tahun 2011). ${ }^{63}$ Sebagai perbandingan: Indonesia berpenduduk sekitar 240 juta orang, dengan wilayah hampir 2 juta kilometer persegi, dengan GDP pc sebesar USD3.980. Artinya, harta dari satu orang Swiss itu kurang-lebih setara dengan harta dari 22 orang Indonesia bersama-sama. Atau jika kita analogikan agak sarkastik dengan perumpamaan pertandingan sepak bola: dari 22 pertandingan melawan Indonesia, Swiss memenangkan 21 daripadanya.

Meskipun bangsa Swiss tidak dapat dipersalahkan untuk kinerja nasional mereka ketimbang kinerja nasional kita, kesenjangan itu sudah pecah sebagai krisis geopolitik tambahan yang pada tingkat global telah menimbulkan ketegangan-ketegangan regional baru. Kita catat misalnya kasus-kasus migran Amerika-Mexiko, kasus pengungsi di Laut Mediterania, tragedi Asia Barat atau di Myanmar/Bangladesh vis-à-vis orang Rohingya, dan tidak jauh-jauh: kasus pekerja migran Indonesia di Malaysia.

Jumlah penduduk yang besar saja tetapi miskin, bodoh dan ditambah dengan tingkat kesehatan yang rendah hanya akan merupakan beban belaka untuk siapapun yang memegang kendali pemerintahan di negara manapun. Apakah kita sudah lupa, bahwa Nusantara yang lebar geografisnya nyaris selebar Amerika Serikat pernah dijajah lama sekali oleh Negeri Belanda yang luasnya (41.500 $\left.\mathrm{km}^{2}\right)$ dan penduduknya (16,7 juta) tidak sampai melebihi Provinsi Jawa Timur $\left(47.800 \mathrm{~km}^{2}\right)$ dengan penduduk (37,5 juta)?64 Pernahkah kita selidiki, mengapa babak sejarah kelam itu sampai pernah bisa terjadi?

Saya tidak mau bersikap pesimistik, tetapi saya memandang perlu untuk melaporkan, menurut pengamatan saya, di mana akar dari ketidakadilan pada tingkat nasional dan global itu bersembunyi.

\footnotetext{
63 Perolehan data dari Februari 2013.

${ }^{64}$ Perolehan data dari Februari 2013.
} 


\section{Apa Yang Sebaiknya Kita Lakukan}

Lalu apa yang sebaiknya kita lakukan untuk menghadapi kelamnya masa depan keadilan pada tingkat nasional maupun global itu? Kita memang tidak bisa mengharapkan bahwa tidak akan terjadi lagi ada orang yang tidak bersalah tetapi dihukum mati seperti di Amerika, atau orang yang sampai kematiannya tidak juga mendapatkan keadilan seperti di India atau Eropa, atau orang-orang miskin yang melakukan kesalahan bagatel dijatuhi hukuman berat seperti di Indonesia. Tetapi kita bisa menjalankan beberapa langkah mendasar untuk paling sedikit mengurangi tingkat ketidakadilan itu.

Langkah mendasar pertama adalah menjadikan best practice sebagai bagian dari kegiatan sehari-hari kita. Setiap hari kita dihadapkan pada pilihan dalam berbagai aspek keseharian, di mana kita harus memilih di antara yang lebih benar dari yang kurang benar, serta yang lebih baik dari yang kurang baik. Dalam keseharian kita bisa kerap menyaksikan keteladanan best practice atau bad practice. Contoh, seperti yang sudah menjadi keseharian di Jakarta, seorang bapak atau ibu yang mengantarkan anaknya ke sekolah sambil melawan arah lalu-lintas tidaklah menjalankan best practice melainkan bad practice yang sangat strategis. Dia sudah menanamkan cara berpikir yang total busuk sejak seorang warganegara kecil harus mulai mengarahkan jalan hidupnya sebagai tabula rasa.

Langkah kedua adalah dengan melaksanakan usaha-usaha yang sungguhsungguh dan konsisten untuk mencerdaskan kehidupan bangsa pada segala strata, dan bukan memperdagangkannya seperti yang sekarang semakin marak di negara kita, dan dimulai sudah di kementerian pendidikan. Kita harus melawan tendensi itu dengan memadukan dua filosofi pendidikan Indonesia sendiri.

Di satu sisi filosofi pendidikan yang dirintis oleh Ki Hajar Dewantara (Suwardi Suryaningrat, 1889-1959) yang melalui Taman Siswa mengajarkan "ing ngarsa sung tuladha, ing madya mangun karsa, tut wuri handayani" yang dalam observasi saya adalah tidak jauh dari Konfusianisme dan cocok untuk membina ketertiban dalam masyarakat yang berkarakter santai dan susah disiplin serta 
beranggapan seolah-olah "segalanya bisa diatur". Di sisi lain adalah filosofi pendidikan dari Engkoe Mohammad Sjafei (1896-1966) yang di Perguruan Kayutanam terutama mengajarkan kemerdekaan berpikir, kemandirian dan etos kerja, yang cocok benar untuk Indonesia yang jujur atau tidak jujur kewalahan menghadapi arus globalisasi. Gagasan dari Engkoe Sjafei mengingatkan saya pada pikiran Max Weber dalam bukunya Die protestantische Ethik und der Geist des Kapitalismus (1904).

Meskipun demikian, hanya pembiasaan best practice dan melakukan investasi pendidikan saja itu mirip dengan kegiatan seorang filosof yang cerdas dan baik hati, tetapi bekerja di menara gading yang tidak pernah didirikan. Langkah ketiga harus dijalankan melalui perlawanan semesta terhadap segala penindasan yang menginjak-injak rasa keadilan, penyalah-gunaan kekuasaan politik maupun kekuatan keuangan. Langkah ketiga ini memang mensyaratkan keberanian dan kesanggupan untuk mobilisasi kehendak seluruh rakyat (Rousseau: volonté de tous) yang tidak gampang. Tetapi jika Jean-Jacques Rousseau (Swiss, 1712-1778) bisa, mengapa kita tidak bisa? Rousseau adalah seorang filosof dan intelektual, kepada siapa intelektual Indonesia harus berteladan.

Memang betul bahwa setiap perlawanan akan meminta korban atau paling sedikit pengorbanan, seperti yang kita selalu diingatkan oleh ujar-ujar yang terpampang di gerbang dari banyak kabupaten dan kecamatan di Jawa Timur: "Jer basuki mawa bea." Itu berarti bahwa untuk mendapatkan keadaan yang lebih baik selalu ada yang harus kita bayar, bahkan juga jika pengorbanan itu ada kalanya harus dibayar oleh mereka yang tidak mampu atau harga pengorbanan yang tidak pantas, karena tidak ada barang gratis yang jatuh dari langit.

Sehubungan dengan soal korban dan pengorbanan ini untuk sementara saya ingat pada dua tokoh perlawanan historis yang telah membebaskan bangsa mereka dari penindasan dan ketidakadilan. Contoh pertama adalah Rousseau yang pikirannya mencetuskan Revolusi Prancis 1789 yang menjadi gerbang bagi 
penguburan absolutisme dan despotisme di Eropa. Konon berucaplah Jenderal Napoleon Bonaparte (Corsica, 1769-1821) ketika menziarahi makam Rousseau: "Demi ketentraman Prancis, orang ini sebaiknya tidak pernah hidup, karena dia telah menyiapkan Revolusi." Contoh kedua adalah mantan tukang listrik di pelabuhan Gdansk/Danzig, Lech Walesa (1943-), yang kerja kerasnya menghasilkan penggulingan kekuasaan otoriter Partai Komunis Polandia dan menjadi "Presiden Pembebasan Polandia” yang pertama.

Ketiga langkah itu bisa dan harus dimulai dari ranah individu dan dibina pada tingkat-tingkat intersubyektif (Jürgen Habermas) sampai ke tataran DPR di Senayan, Istana Presiden dan Mahkamah Agung di Jalan Medan Merdeka Utara.

\section{Daftar Pustaka}

\section{Buku:}

Alfred Sellner, Latein im Alltag, Wiesbaden: VMA-Verlag, 1980.

Antoon Vloemans, Politeia, Geschiedenis van de sociaal politieke filosofie, Den Haag: Kruseman's, 1971, merujuk pada karya Cicero: De Legibus, I, 2.

Aristoteles, Politika, sebagaimana dikutip oleh Arno Baruzzi dalam Heinz Rausch, (Ed.). Politische Denker, Band I, II, III, München: Bayerische Landeszentrale für Politische Bildungsarbeit, 1977.

Bernd Rüthers, Rechtstheorie, München: CH Beck, 2005.

Bernd Rüthers, Das Ungerechte an der Gerechtigkeit, Tübingen: Mohr Siebeck, 2009.

Budiono Kusumohamidjojo, "Seratus Tahun Ernst Bloch, Prinsip Pengharapan", dalam: Sinar Harapan, 1985-07-10.

Budiono Kusumohamidjojo, Filsafat Hukum: Problematik Ketertiban yang Adil, Jakarta: Grasindo, 2004.

Budiono Kusumohamidjojo, Filsafat Kebudayaan: Proses Realisasi Manusia, Yogyakarta: Jalasutra, 2009.

Budiono Kusumohamidjojo, Filsafat Politik: Kotak Pandora Abad ke-21, Yogyakarta: Jalasutra, 2015.

Confucius, Confucian Analects, The Great Learning \& The Doctrine of the Mean, New York: Dover Publications Inc., (terjemahan text asli oleh James Legge), [1893] 1971.

Ulrich Beck, What is Globalization?, Cambridge: Polity, 2003.

Ernst Bloch, Das Prinzip Hoffung, Band I-III, Frankfurt/Main: Suhrkamp, 1979.

Fung Yulan, A Short History of Chinese Philosophy, New York etc.: The Free Press, [1948]. 
Friedrich Nietzsche, "Zur Naturgeschichte der Moral", dalam: Jenseits von Gut und Böse: Vorspiel einer Philosophie der Zukunft, (1886) München: Goldmann Verlag: 1996.

Fritjof Capra, The Tao of Physics: An Exploration of the Parallels Between Modern Physics and Eastern Mysticism, Toronto/New York/London: Bantam, [1975] 1980.

Gaetano Mosca, The Ruling Class, New York, Toronto, and London: McGraw-Hill, 1939 (pertama kali terbit dalam tahun 1884 dengan judul (Italia) Elementi di scienza politica).

Gunnar Skirrbek \& Nils Gilje, Geshichte der Philosophie, Eine Einführung in die europäische Philosophiegeschichte, Band I, München: Suhrkamp, [1987] 1993.

Haing Ngor \& Roger Warner, Survival in the Killing Fields. New York: Carroll \& Graf, 2003.

Heinrich Honsell, Römisches Recht, Berlin/Heidelberg/New York: Springer, 2002.

Immanuel Kant, , Grundlegung zur Metaphysik der Sitten, Stuttgart: Philipp Reclam, [1786] 1976).

Immanuel Kelsen, Was ist Gerechtigkeit?, Stuttgart: Philipp Reclam, 2010.

John Deigh, "Freud's Later Theory of Civilization: Changes and Implications", dalam Jerome Neu, (ed.), The Cambridge Companion to Freud, Cambridge University Press, [1991] 1999.

Jee Loo Liu, An Introduction To Chinese Philosophy: from Ancient Philosophy to Chinese Buddhism, Malden MA: Blackwell, [2006] 2008.

Jürgen Habermas, Die postnationale Konstellation: Politische Essays, Frankfurt/Main: Suhrkamp, 1998.

Karl Popper, "Oracular Philosophy and the Revolt against Reason", dalam: The Open Society and Its Enemies, Princeton UP [1945] 1971: Vol. 2, Ch. 24.

Konfuzius, Gespräche. Lun Yü, versi Jerman dari Richard Wilhelm, München: dtv CH Beck, [2005] 2007.

Max Weber, Politik als Beruf, Berlin: Duncker \& Humblot, 1926.

Michael Sandel, Justice: What's the Right Thing to do? New York: Farrar, Straus \& Giroux, 2009.

Niccolo Machiavelli, Der Fürst, (dari versi Italia: Il Principe, oleh Rudolf Zorn), Stuttgart/Alfred Kröner Verlag, 1977.

Niccolo Machiavelli, Discorsi, Gedanken über Politik und Staatsführung, (dari versi Italia: Discorsi Sopra la Prima Deca di Tito Livio, 1513-1522, oleh Rudolf Zorn), Stuttgart: Alfred Kröner Verlag, 1977.

Otfried Höffe, Gerechtigkeit: Eine philosophische Einführung, München: C.H. Beck, 2010.

Reinhold Zippelius, Geschichte der Staatsideen, München: Beck, 1980.

Ronald Dworkin, "Integrity in Law", dalam: Law's Empire, Harvard UP, 1986: 225276.

Satjipto Rahardjo, Ilmu Hukum, Bandung: PT Citra Aditya Bakti, 2000. 
Sigmund Freud, Das Unbehagen in der Kultur, Frankfurt/Main: Fischer Taschenbuch Verlag, [1930] 2007.

Theo Huijbers, Filsafat Hukum, Yogyakarta, Kanisius, 1991.

Thomas Hobbes, Leviathan, (dari versi Inggris oleh Jacob Peter Mayer), Stuttgart: Philipp Reclam, 1980.

Will Kymlicka, Contemporary Political Philosophy: An Introduction, Oxford UP, [1990] 1997.

\section{Jurnal:}

Budiono Kusumohamidjojo, "Han Feizi's Political Philosophy and Today's China", dalam: MELINTAS: An International Journal of Philosophy and Religion, Department of Philosophy, Parahyangan University, Bandung - Indonesia, ISSN 0952-0089, Vol. 25 No. 1, April 2009, pp. 45-56.

\section{Majalah:}

Jason Oberdorf, “Unclogging the Courts", dalam Newsweek, 18 July 2005.

\section{Surat Kabar:}

Budiono Kusumohamidjojo, "Law and mafia democracy", dalam: The Jakarta Post, Monday, January 30, 2012.

\section{Websites}

Death penalties exonerated, dalam: http://www.deathpenaltyinfo.org/innocencelist-those-freed-death-row, 21-11-2014.

detikNews, Kamis 19 Nov 2009, 15:24 WIB, dalam: http://news.detik.com/ berita/1244955/mencuri-3-buah-kakao-nenek-minah-dihukum-1-bulan15-hari, 24-06-2015.

Ereteken voor Orde en Vrede, Wikipedia, https://nl.wikipedia.org/wiki/ Ereteken_voor_Orde_en_Vrede, 23-06-2015.

"The life of Harry S. Truman," dari buku "The Time of Stalin: Portrait of Tyranny" yang ditulis oleh Anton Antonov-Ovseyenko, halaman 278. Lihat: http://en.wikiquote.org/wiki/Joseph_Stalin, Retrieved from http://en. wikipedia.org/w/index.php?title=Joseph_Stalin\&oldid=1467097, 21-092012.

Marx, Karl, Zur Kritik der politischen Ökonomie (1859), Vorwort, dari: https://de.wikipedia.org/wiki/Basis_und_\%C3\%9Cberbau (2015-06-22).

"Modernisasi Yang Empat" (Sì gè xiàndàihuà), dari: The Four Modernizations, dalam: https://en.wikipedia.org/?title=Four_Modernizations, 25-06-2015.

Obama, Barack Hussein, Pidato kemenangan untuk masa jabatan kedua, 06 November 2012, Transcript: Obama's victory speech, http://politicalticker. blogs.cnn.com/2012/11/07/transcript-obamas-victory-speech/, 14-112013. 
Stiglitz, Joseph (May 2011). "Of the $1 \%$, by the $1 \%$, for the $1 \%$ ", dalam: http://www.vanityfair.com/news/2011/05/top-one-percent-201105, 2107-2015.

Tunas Bangsa, 9 Januari 2012, dalam: http://www.tubasmedia.com/pencurisandal-jepit-5-tahun-penjara-koruptor-15-tahun/, 24-06-2015.

World Population, dalam: Wikipedia, http://en.wikipedia.org/wiki/ World_population, retrieved from http://en.wikipedia.org/w/index.php? title=World_population\&oldid=516918221, 11-10-2012. 